\title{
Hubungan Pengetahuan Dengan Kinerja Bidan Dalam Penerapan Standar Pelayanan Antenatal Care 10 T
}

\author{
Feilan Carolina Lasut, ${ }^{1}$, Amelia Donsu, ${ }^{2}$ \\ ${ }^{1}$ Akademi Kebidanan Trinita Manado, feilancarolina@gmail.com \\ ${ }^{2}$ Jurusan Kebidanan Poltekkes Kemenkes Manado,Amelia.donsu@yahoo.com
}

Naskah Diterima : sepetember $2018 \quad$ Disetujui : spetember $2018 \quad$ Publikasi : Januari 2019

\begin{abstract}
ABSTRAK
Latar belakang : Antenatal Care (ANC) merupakan layanan kesehatan yang diberikan oleh tenaga kesehatan yang sudah terlatih untuk ibu hamil selama masa kehamilan, sesuai dengan Standar Pelayanan Kebidanan. Menurut Survey Demografi Kesehatan Indonesia (SDKI) tahun 2012 mencatat Angka Kematian Ibu (AKI) naik dari 228 menjadi 359 per 100.000 kelahiran hidup. Data yang diperoleh dari Puskesmas Popayato Timur dan Popayato Induk tahun 2016 jumlah ibu hamil 524 orang, tahun 2017 K1 183 orang dan K4 141 orang,

Tujuan : Penelitian ini bertujuan untuk mengetahui hubungan pengetahuan dengan kinerja bidan dalam penerapan standar pelayanan antenatal care 10T di wilayah kerja Puskesmas Popayato Timur dan Popayato Induk Kabupaten Pohuwato Gorontalo Tahun 2017.

Metode : Jenis penelitian ini bersifat survei analitik dengan desain kuantitatif menggunakan pendekatan cross sectional study. Populasi penelitian ini meliputi seluruh bidan yang ada di Puskesmas Popayato Timur dan Popayato Induk Kabupaten Pohuwato berjumlah 32 orang, yang semuanya dijadikan sampel. Pengumpulan data melalui kuesioner. Analisis data secara univariat dan bivariat menggunakan uji Chi Square.

Hasil : penelitian ini menunjukkan ada hubungan antara pengetahuan dengan kinerja bidan dalam penerapan standar pelayanan antenatal care $10 \mathrm{~T}$ di wilayah kerja Puskesmas Popayato Timur dan Popayato Induk Kabupaten Pohuwato Gorontalo tahun 2017 pada tingkat signifikansi $0.001(\mathrm{p}<0.05)$. rekomendasi agar bidan ataupun petugas kesehatan yang ada di Puskesmas Popayato Timur dan Popayato Induk meningkatkan ilmu pengetahun terkait dengan pelayanan ANC serta melengkapi fasilitas kesehatan sesuai standar pelayanan ANC $10 \mathrm{~T}$
\end{abstract}

\section{Kata Kunci : Pengetahuan, kinerja bidan, ANC 10T}

\section{PENDAHULUAN}

Antenatal Care (ANC) adalah layanan kesehatan yang diberikan oleh tenaga kesehatan yang sudah terlatih untuk ibu hamil selama masa kehamilan-sesuai standar pelayanan antenatal yang sudah ditetapkan dalam Standar Pelayanan Kebidanan. Salah satu penyebab AKI dan AKB karena masih rendahnya tingkat kesadaran ibu hamil untuk melakukan pemeriksaan kehamilan atau antenatal care ${ }^{(\mathbf{1})}$ AKI merupakan salah satu indikator untuk melihat derajat kesehatan perempuan. Angka kematian ibu juga merupakan salah satu target yang telah ditentukan dalam Sustainable Development Goal's (SDG's) tujuan ke 3 yaitu memastikan kehidupan yang sehat dan mendukung kesejahteraan bagi semua untuk semua usia, dimana salah satu target menurunkan AKI, AKB dan Angka Kematian Neonatal (AKN) Tahun 2030 (2) Data menunjukkan bahwa AKI telah mengalami penurunan dari waktu ke waktu, namun demikian upaya untuk mewujudkan target tujuan pembangunan millennium masih membutuhkan komitmen usaha keras yang terus menerus. Berdasarkan SDKI tahun 2012 AKI di Indonesia 359 per 100.000 kelahiran 
hidup dan AKB 32/1000 kelahiran hidup. Pada tahun 2015, berdasarkan data SUPAS 2015 AKI menurun 305/100.000 kelahiran hidup dan AKB 22/1000 kelahiran hidup (3)

Kehamilan resiko tinggi dapat dideteksi apabila ibu hamil melakukan pemeriksaan (ANC) secara rutin. Ibu hamil sekurangkurangnya menerima pemeriksaan hamil empat kali sesuai standar dengan distribusi satu kali pada trimester satu satu kali pada trimester dua dan dua kali pada trimester tiga. Termasuk didalam pelayanan ini adalah deteksi tanda bahaya/resiko tinggi, serta pemberian informasi tentang upaya menjaga kehamilan dan mempersiapkan persalinan agar persalinan berjalan dengan baik. ${ }^{(4)}$ Hal ini dilakukan bidan untuk nenilai apakah perkembangan ibu dan janin berlangsung normal. Bidan juga harus mengenal kehamilan resiko tinggi/kelainan serta tugas terkait lainnya yang diberikan oleh Puskesmas. Bidan harus mencatat data yang tepat pada setiap kunjungan. Bila ditemukan kelainan, bidan harus mampu mengambil tindakan yang diperlukan dan merujuk untuk tindakan selanjutnya. (5)

Sesuai dengan kompetensi bidan yang ketiga yaitu memberikan asuhan antenatal bermutu tinggi untuk mengoptimalkan kesehatan selama kehamilan. ${ }^{(6)}$ Tindakan ini didukung oleh Pemerintah dengan Kepmenkes Nomor 938/Menkes/SK/VIII/2007 tentang standar asuhan kebidanan dan Permenkes nomor 1464/Menkes/X/2010 tentang izin dan penyelenggaraan praktik kebidanan.

Data dari Puskesmas Popayato Timur, tahun 2016 jumlah ibu hamil 158 orang, tahun 2017 pada bulan Januari sampai bulan Juni ibu hamil yang datang berkunjung pertama (K1) 81 orang, kunjungan keempat (K4) 63 orang. Sementara di Puskesmas Popayato Induk tahun 2016 didapatkan jumlah ibu hamil mencapai 366 orang dan bulan Januari sampai bulan Juni tahun 2017 (K 1) 102 orang, (K4)
78 orang, masih ditemukannya kematian

(8)(9) Data ini menunjukkan

neonatus. cakupan persalinan Termasuk dalam kategori rendah serta mempengaruhi percepatan penurunan angka kematian ibu dan bayi yang berdampak pada kinerja bidan dalam pertolongan persalinan belum optimal. Belum optimalnya kinerja bidan terutama dalam upaya adanya penurunan kinerja bidan Puskesmas dalam penanganan ibu hamil resiko tinggi.

Sehubungan dengan rendahnya kinerja bidan ini bisa dipengaruhi oleh kemampuan dan Pengalaman, kualitas sumber daya kesehatan khususnya tenaga bidan yang menunjukkan latar belakang tingakat pendidikan, penghargaan yang diterima serta peralatan dan beban kerja yang tidak berhubungan langsung dengan tugas pokok dan fungsinya sebagai bidan mengalami kejenuhan, terutama tugastugas yang bersifat administratif sehingga berdampak kepada angka cakupan dan mutu pertolongan persalinan. Penelitian ini bertujuan untuk mengetahui hubungan pengetahuan dengan kinerja bidan dalam penerapan standar pelayanan antenatal care 10T di wilayah kerja Puskesmas Popayato Timur dan Popayato Induk Kabupaten Pohuwato Gorontalo Tahun 2017.

\section{METODE}

Jenis penelitian survey analitik dengan pendekatan cross sectional. Populasi seluruh bidan yang ada di Puskesmas Popayato Timur dan Popayato Induk Kabupaten yang berjumlah 32 Bidan dijadikan sampel dalam penelitian ini. Variabel bebas adalah pengetahuan, variabel terikat adalah kinerja bidan dalam penerapan standar pelayanan ANC $10 \mathrm{~T}$. Pengumpulan data menggunakan 
kuesioner wawancara dan pengamatan.

Analisis data univariat dan bivariate

\section{HASIL}

Analisis Univariat

Tabel 1. Distribusi Responden menurut tingkat pendidikan, umur, tingkat pengetahuan dan kinerja bidan di Wilayah Kerja Puskesmas Popayato Timur dan Popayato Induk Kabupaten Pohuwato Gorontalo tahun 2017

\begin{tabular}{lcc}
\hline \multicolumn{1}{c}{ Variabel } & $\mathrm{f}(\mathrm{n}=32)$ & $\%$ \\
\hline Pendidikan : & & \\
D I & 4 & 12,5 \\
D III & 28 & 87,5 \\
\hline Umur : & & \\
20 - 35 tahun & 26 & 81,2 \\
$\quad$ > 35 tahun & 6 & 18,8 \\
\hline Tingkat Pengetahuan : & 28 & \\
$\quad$ Baik & 4 & 87,5 \\
$\quad$ Cukup & & 12,5 \\
Kinerja Bidan : & 27 & 84,4 \\
Baik & 5 & 15,6 \\
Cukup &
\end{tabular}

Tabel 1 menunjukkan bahwa distribusi responden menurut umur terbanyak adalah 20 tingkat pendidikan responden terbanyak adalah - 35 tahun, tingkat pengetahuan responden D III sebanyak 28 responden (87.5\%), D I sebanyak 4 responden ( $12.5 \%)$, distribusi terbanyak adalah baik, dan kinerja responden baik

Analisis Bivariat

Tabel 2 Analisis Hubungan Tingkat Pengetahuan Dengan Kinerja Bidan Dalam Penerapan Standar Pelayanan Antenatal Care 10 T Di Wilayah Kerja Puskesmas Popayato Timur Dan Popayato Induk Kabupaten Pohuwato Gorontalo Tahun 2017

\begin{tabular}{cccccccc}
\hline \multirow{2}{*}{ Pengetahuan } & \multicolumn{4}{c}{ Kinerja Bidan } & \multicolumn{2}{c}{ Total } & \multirow{2}{*}{ p } \\
\cline { 2 - 6 } & \multicolumn{3}{c}{ Baik } & \multicolumn{2}{c}{ Cukup } & & \\
\cline { 2 - 6 } & $\mathrm{f}$ & $\%$ & $\mathrm{f}$ & $\%$ & $\mathrm{f}$ & $\%$ & \\
\hline Baik & 27 & 84,4 & 1 & 3,1 & 28 & 87,5 & 0.001 \\
\hline Cukup & 0 & 0 & 4 & 12,5 & 4 & 12,5 & \\
\hline Total & 27 & 84,4 & 5 & 15,6 & 32 & 100 & \\
\hline
\end{tabular}

Sumber : Data Primer Penelitian Tahun 2017

Di lihat dari tabel 2 menunjukkan hubungan tingkat pengetahuan terhadap kinerja bidan dalam penerapan standar pelayanan antenatal care $10 \mathrm{~T}$, responden yang berpengetahuan baik dan memiliki kinerja baik sebanyak 27 responden $(84,4 \%)$, yang memiliki kinerja cukup sebanyak 1 responden $(3,1 \%)$. Tidak ada responden yang berpengetahuan cukup memiliki kinerja baik. Responden yang memiliki penegtahuan cukup dengan kinerja cukup 4 responden (12,5\%). Analisis statistik untuk menguji hubungan adalah chi square. Nilai yang diperoleh 0,001 ( $\mathrm{p}$ value $<0,05$ ) artinya terdapat hubungan antara tingkat pengetahuan dengan kinerja 
bidan dalam penerapan standar pelayanan antenatal care $10 \mathrm{~T}$.

\section{PEMBAHASAN}

Kelompok umur terbesar yaitu $20-$ 35 tahun dibandingkan dengan kelompok umur >35 tahun, umur responden sebagian besar berada pada umur produktif, kinerja bidan dari hasil penelitian ini juga dipengaruhi oleh pendidikan terakhir bidan yang paling banyak adalah diploma III sisamya denhgan latar belakang pendidikan DI, pengetahuan bidan tentang penerapan standar pelayanan antenatal care 10T lebih banyak dalam kategori baik dibandingkan dengan cukup, selanjutnya kinerja Bidan sebagian besar dalam kategori baik dibandingkan dengan cukup (tabel 1)

Penelitian ini menunujukkan bahwa fasilitas yang digunakan dalam pelayanan antenatal care ada beberapa fasilitas yang sudah rusak tetapi ada juga yang masih dalam keadaan bagus. Meskipun dalam keadaan bagus, pemeriksaan ANC di Puskesmas Popayato Timur dan Induk masih belum bisa dikatakan sesuai dengan standar pemeriksaan ANC 10T karena tidak adanya ruangan yang memadai untuk melakukan pemeriksaan ANC seperti laboratorium yang harusnya di pakai untuk melakukan pemeriksaan urine protein, pemeriksaan $\mathrm{Hb}$ dan pemeriksaan HIV. Ini menjadi salah satu kendala bagi bidan untuk melakukan pemeriksaan ANC dikarenakan tidak ada ruangan yang memadai sehingga pelayanan standar ANC 10T tidak dilakukan secara maksimal.

Hubungan pengetahuan dengan kinerja bidan dalam penerapan standar pelayanan antenatal care $10 \mathrm{~T}$ di wilayah kerja Puskesmas Popayato Timur dan Popayato Induk. Hasil penelitian, responden dengan pengetahuan baik sebanyak 28 responden $(87,5 \%)$ di bandingkan dengan responden pengetahuan cukup sebanyak 4 responden (12, 5\%). Dari hasil analisis statistik menggunakan uji chi square, nilai signifikan antara tingkat pengetahuan dengan kinerja bidan yaitu 0,001 ( $p$ value $<0,05)$ yang berarti ada hubungan antara tingkat pengetahuan dengan kinerja bidan dalam penerapan standar pelayanan antenatal care 10T (tabel 2). Hal ini juga sesuai dengan teori yang mengatakan bahwa pengetahuan adalah merupakan hasil "tahu" dan ini terjadi setelah orang yang melakukan pengindraan terhadap suatu objek tertentu. Pengindraan terhadap suatu objek dapat karena panca indra manusia yaitu penglihatan, pendengaran, penciuman, perasa dan peraba. Pada waktu pengindraan sampai menghasilkan pengetahuan tersebut sangat dipengaruhi oleh intensitas perhatian persepsi terhadap objek. Sebagian besar pengetahuan manusia diperoleh malalui mata dan telinga. (11) kinerja seorang bidan dipengaruhi oleh salah satu faktor yaitu kemampuan, semakin tinggi kemampuan seseorang akan semakin banyak tugas atau pekerjaan yang dapat diselesaikan dalam periode tertentu maka akan merepresentasikan besarnya kuantitas kinerja yang dihasilkan. Dalam Pelayanan kesehatan yang dilakukan bidan akan terlaksanakan secara optimal apabila setiap bidan memahami komitmen kerjanya sebagai bidan, kecenderungan ini didukung oleh teori yang menyatakan bahwa salah satu faktor yang mempengaruhi terhadap kinerja adalah kemampuan. Apabila kemampuan yang dimiliki seseorang terhadap suatu 
pekerjaan sangat minim, maka akan menghasikan tingkat kinerja yang rendah. (12)

Dari hasil pengamatan di Puskesmas Popayato Timur dan Popayato Induk responden pengetahuan baik dengan kinerja baik sebanyak 27 responden (84,4\%) dan kinerja cukup sebanyak 1 responden $(3,2 \%)$. Sedangkan responden pengetahuan cukup dengan kinerja baik sebanyak 0 responden $(0 \%)$ dan kinerja cukup sebanyak 4 responden (12,5\%).

Penelitian ini sejalan dengan penelitian sebelumnya yang menunjukkan ada hubungan antara pengetahuan dengan kinerja bidan terhadap ANC dimana pengetahuan dipengaruhi oleh intelektual dan tingkat pemahaman bidan khususnya kompetensi bidan terhadap penerapan standar pelayanan ANC (13) Tapi kinerja seseorang merupakan gabungan dari kemampuan, usaha, dan kesempatan, yang dapat diukur dari akibat yang dihasilkan. Selanjutnya penelitian ini tidak sejalan dengan hasil penelitian yang di lakukan Di Puskesmas Rawat Inap Kabupaten Gresik yang mengatakan bahwa tidak ada hubungan antara pengetahuan dengan kinerja bidan dalam pelaksanaan standar asuhan kebidanan antenatal care.

Pengetahuan merupakan kemampuan intelektual dan tingkat pemahaman bidan terutama kompetensi bidan terhadap penerapan standar pelayanan ANC sesuai pendidikan kebidanan, yang mempengaruhi bidan dalam memberikan pelayanan kepada masyarakat khususnya ibu hamil yang secara langsung maupun tidak langsung akan berdampak pada kinerja bidan.

\section{KESIMPULAN}

Pengetahuan bidan tentang penerapan standar pelayanan antenatal care 10T di wilayah kerja puskesmas Popayato Timur dan Popayato Induk sebagian besar adalah baik namun masih ada yang berpengetahuan cukup.

Ada hubungan antara pengetahuan dengan kinerja bidan dalam penerapan standar pelayanan antenatal care di wilayah kerja puskesmas Popayato Timur dan Popayato Induk Kabupaten Pohuwato Gorontalo Tahun 2017.

\section{SARAN}

Bagi petugas kesehatan di Puskesmas Popayato Timur dan Popayato Induk untuk lebih memperhatikan serta melengkapi fasilitas pelayanan kesehatan khususnya pada pelayanan antenatal care agar lebih menunjang pelayanan antenatal care. Agar melaksanakan pemeriksaan antenatal care sesuai dengan standar pelayanan antenatal care $10 \mathrm{~T}$.

\section{UCAPAN TERIMA KASIH}

Terima kasih kepada Tuhan atas berkat anugerahnya, Direktur Akademi Kebidanan Trinita Manado Bapak Demsi R. Sasewa, S.Sos, SE, M.Si yang selalu memberikan dukungan selama penelitian, dan rekan dosen Poltekkes Kemenkes Manado Ibu Amelia Donsu, SST, M.Kes yang banyak memberikan bantuan, bersama melakukan penelitian ini hingga bisa selesai dengan baik.

\section{DAFTAR PUSTAKA}

1. Depkes RI. Pedoman Pemantauan Wilayah Setempat Kesehatan Ibu Dan Ana. Jakarta: Direktorat Jenderal Bina Kesehatan Keluarga; 2009. 
2. INFID. Tujuan Sustainable Development Goal's. 2017.

3. Kemenkes RI. Laporan Tahunan Direktorat Kesehatan Keluarga [Internet]. 2016 [cited 2017 Jul 14]. Available from: http://www.kesga.kemkes.go.id.images.pedoman

4. Depkes RI. Pedoman Pengembangan Obstetri-Neonatal Emergensi Dasar (PONED). Jakarta: Depkes; 2014.

5. Mellani N, Setiyawati N ED. Kebidanan Komunitas. Yogyakarta: Fitramaya; 2009.

6. Mangkunegara A.P. Evaluasi Kinerja SDM. Bandung: Reflika Aditama; 2010.

7. Ardiani N. Organisasi; Perilaku, Struktur, Proses. Jakarta: Binarupa Aksara; 2010.

8. Puskesmas Popayato Timur. Profil Kesehatan Puskesmas Popayato Timur. Gorontalo; 2016.

9. Kesehatan Puskesmas Popayato Induk. Profil Kesehatan Puskesmas Popayato Induk. Gorontalo; 2016.

10. Arikunto S. Prosedur Penelitian Suatu Pendekatan Praktek. Jakarta: Rineka Cipta; 2013.

11. Notoadmodjo S. Promosi Kesehatan dan Perilaku Kesehatan. Jakarta: Rineka Cipta; 2012.

12. Timple AD. The Art And Scicien of Business Management Leadership. Jakarta: Gramedia; 2002.

13. Lamere L, Nurhayani, Hamzah A. Analisis Kinerja Bidan Pada Pelayanan Antenatal Care Di Puskesmas Sekabupaten Gowa. Hasanudidin University. 2013. p. 1-11.

14. Hamidah S, Widagdo L, Wulan. RLK. Faktor-Faktor yang Berpengaruh terhadap Kinerja Bidan dalam Pelaksanaan Standar Asuhan Kebidanan Antenatal Care di Puskesmas Rawat Inap Kabupaten Gresik. J Manaj Kesehat Indones. 2014;2(1):59-70. 